DOI: https://doi.org/10.47405/mjssh.v6i2.671

\begin{tabular}{|c|c|}
\hline & Malaysian Journal of Social Sciences and Humanities (MJSSH) \\
\hline Malaysian Journal of & Volume 6, Issue 2, February 2021 \\
\hline $\begin{array}{l}\text { Humanities } \\
\text { (mJ-sst) }\end{array}$ & e-ISSN : 2504-8562 \\
\hline & $\begin{array}{l}\text { Journal home page: } \\
\text { www.msocialsciences.com }\end{array}$ \\
\hline
\end{tabular}

\title{
Hubungan antara Pengetahuan dan Sikap Terhadap Homoseksual dalam kalangan Pelajar Sekolah Agama
}

\author{
Siti Nabilah Zaini' ${ }^{,}$, Shahlan Surat', Salleh Amat1 \\ ${ }^{1}$ Fakulti Pendidikan, Universiti Kebangsaan Malaysia (UKM) \\ Correspondence: Siti Nabilah Zaini (p98394@siswa.ukm.edu.my)
}

\begin{abstract}
Abstrak
Fenomena homoseksual telah mewujudkan diskriminasi, prejudis dan sikap yang negatif dalam kalangan masyarakat. Kajian ini dijalankan untuk mengenal pasti hubungan antara pengetahuan homoseksual dengan sikap terhadap homoseksual dalam kalangan pelajar sekolah agama di daerah Kulim. Kajian ini adalah berbentuk kuantitatif dengan menggunakan reka bentuk tinjauan. Data dikumpulkan menggunakan soal selidik dan diedarkan kepada 136 orang pelajar tingkatan empat, lima dan enam daripada dua buah sekolah menengah agama. Soal selidik dalam kajian ini menggunakan dua jenis instrumen iaitu The Sex Education and Knowledge about Homosexuality (SEKHQ) dan The Attitudes Towards Homosexuals Questionnaire (AHQ). Kemudian, data kajian dianalisis menggunakan statistik deskriptif dan statistik inferensi yang melibatkan ujian-t, ujian ANOVA dan Korelasi Pearson dengan menggunakan perisian Statistial Packages for Social Sciences (SPSS) versi 20. Hasil dapatan mendapati tidak ada perbezaan yang signifikan $(\mathrm{p}>0.05)$ di dalam pengetahuan homoseksual dan sikap terhadap homoseksual berdasarkan jantina dan umur pelajar. Selain itu, kajian juga menunjukkan bahawa pengetahuan homoseksual $(r=0.034, p>0.05)$ tidak mempunyai hubungan yang signifikan dengan sikap terhadap homoseksual dalam kalangan pelajar sekolah agama. Secara kesimpulan, pengetahuan pelajar tentang homoseksual tidak mempengaruhi sikap pelajar sekolah agama terhadap homoseksual. Oleh yang demikian, kajian ini menunjukkan bahawa semakin tinggi pengetahuan tentang homoseksual, maka ia akan menghasilkan sikap yang negatif terhadap homoseksual. Pengetahuan yang tinggi mengenai homoseksual tetap tidak membuatkan pelajar terbuka dalam menerima fenomena ini sebagai gaya hidup.
\end{abstract}

Kata kunci: pengetahuan, sikap, homoseksual

\section{The Relationship between Knowledge and Attitude Towards Homosexuality among Islamic School Students}

\begin{abstract}
Homosexuality is a strictly-opposed way of life against the Malaysian societal norms which has been increased from year to year. This phenomenon has created discrimination, prejudice, and negative attitudes in society. Therefore, the objective of this study is to discuss and identify the relationship between homosexual knowledge and attitudes towards homosexuality among islamic school students in Kulim district. This study was conducted in quantitative form using survey design. Data was collected using questionnaires and distributed to 136 form four, form five, and form six students from two islamic secondary schools. Two instruments were used in this study namely The Sex Education and Knowledge about Homosexuality (SEKHQ) and The Attitudes Towards Homosexuals Questionnaire
\end{abstract}


(AHQ). The study data were analyzed using descriptive statistics and inferential statistics involving ttest, ANOVA test, and Pearson Correlation using Statistical Packages for Social Sciences (SPSS) version 20 software. The findings showed that there was no significant difference $(p>0.05)$ in homosexual knowledge and attitudes towards homosexuality based on students' gender and age. Besides, the study also showed that homosexual knowledge $(r=0.034, p>0.05)$ did not have a significant relationship with attitudes towards homosexuality among islamic school students. In conclusion, students' knowledge of homosexuality does not affect the attitude of islamic school students towards homosexuality. Thus, this study shows that the higher the knowledge of homosexuals, then it will result in a negative attitude towards homosexuality. High knowledge of homosexuality still does not make students open in accepting this phenomenon as a lifestyle.

Keywords: Knowledge, Attitude, Homosexuals

\section{Pengenalan}

Orientasi seksual bermaksud seseorang individu yang tertarik secara emosi, seksual, romantik dan fizikal untuk memenuhi rasa cinta dan berhubungan secara intim terhadap jenis jantina yang tertentu. Orientasi seksual boleh dibahagi kepada beberapa jenis dan heteroseksual merupakan orientasi seksual dalam kumpulan kebanyakan iaitu tarikan naluri seksual terhadap individu yang berlainan jantina. Manakala, homoseksual pula merujuk kepada individu yang mempunyai kecenderungan atau orientasi seksual terhadap sama jantina yang dikenali sebagai gay dan lesbian (Sadock et al., 2015). Gay merupakan istilah yang digunakan terhadap individu lelaki yang homoseksual, manakala istilah bagi wanita homoseksual pula adalah lesbian (Hogan \& Hudson, 1998).

Budaya homoseksual tidak hanya menular dalam kalangan golongan bukan Islam, tetapi juga ia semakin mendapat tempat dalam kalangan golongan beragama Islam. Golongan ini disisihkan dan dikritik oleh masyarakat Malaysia kerana budaya ini sangat bertentangan dengan adat dan agama serta institusi kekeluargaan. Beberapa negara luar berkemungkinan menerima baik fenomena homoseksual ini. Namun di Malaysia, budaya homoseksual ini dikira sebagai satu budaya yang telah melanggar norma masyarakat kerana ia secara jelas telah melanggar hukum agama dan menyimpang daripada budaya di negara ini. Fenomena yang menyimpang daripada ajaran agama ini telah mencetuskan kontroversi kerana tidak selari dengan perlembagaan Malaysia, malah bertentangan dengan agama dan nilai budaya dalam masyarakat Malaysia (Puteri \& Nurul, 2015; Roslee et al., 2017; Suhaya, 2017). Walau bagaimanapun, terdapat beberapa organisasi bukan kerajaan di Malaysia yang menyokong dan memperjuangkan aktiviti golongan ini dengan tujuan untuk mendapatkan hak dan pengiktirafan (Khairul, 2015; Mohamad Afandi \& Mohd Sabree, 2019).

Pada asalnya, homoseksual pernah diklasifikasikan sebagai suatu penyakit atau gangguan mental dalam Manual Diagnostik dan Statistik Gangguan Mental III (DSM III). Namun pada tahun 1973, American Psychiatric Association (APA) telah membuat undian berkenaan isu homoseksual sama ada ia sesuai untuk diklasifikasikan sebagai gangguan mental ataupun tidak dan hasil keputusannya, homoseksual dikeluarkan daripada Manual Diagnostik dan Statistik Gangguan Mental (DSM). Walaupun begitu, homoseksual tetap tidak dapat lari daripada masalah kesihatan mental. Menurut Amarican Psychiatric Association (2017), golongan homoseksual mempunyai masalah kesihatan mental yang lebih tinggi berbanding individu heteroseksual.

Di Malaysia, fenomena homoseksual merupakan sesuatu yang taboo dan masih janggal dalam kalangan masyarakat. Pola pemikiran yang negatif akan turut mencetuskan sikap yang negatif dalam sesebuah masyarakat. Sikap masyarakat yang menentang fenomena homoseksual ini telah disebar secara meluas oleh organisasi keagamaan. Hal ini akan turut mencetuskan sikap yang negatif dalam masyarakat sekeliling dan seterusnya stigma dalam kalangan masyarakat ini akan memberi kesan terhadap golongan profesional yang perlu berhadapan dengan golongan homoseksual. Sikap merangkumi tiga aspek iaitu kognitif, tingkah laku dan afektif. Oleh itu, sikap didefinisikan sebagai perasaan, idea, prasangka atau kepercayaan yang dimiliki oleh seseorang yang mana akan mempengaruhi penerimaan 
seseorang individu terhadap sesuatu perkara. Kajian mengenai sikap terhadap homoseksual telah banyak dijalankan di negara-negara luar termasuk negara Malaysia. Antara negara-negara yang menjalankan kajian sikap terhadap homoseksual ini ialah India (Siva et al., 2020), Itali (Della et al., 2018), Malaysia (Ng, 2013), Kanada (Schellenberg et al., 1999) dan lain-lain lagi.

Menurut Osmanaga (2015), faktor jantina, bangsa, kepercayaan diri dan tahap pendidikan boleh mempengaruhi sikap terhadap homoseksual. Selain itu, beberapa kajian turut menyatakan bahawa orientasi seksual seseorang mampu memberi kesan terhadap sikap individu di sekeliling. Orientasi seksual golongan minoriti seperti homoseksual sering terdedah dengan stereotaip, kebencian dan diskriminasi oleh masyarakat sekeliling. Istilah yang tepat bagi menggambarkan situasi ini ialah homofobia. Istilah ini digunakan bagi menggambarkan sikap negatif seseorang terhadap homoseksual. Homofobia ditakrifkan sebagai ketakutan yang tidak rasional terhadap homoseksual sehingga mempengaruhi kepercayaan dan sikap mereka terhadap golongan ini. Secara umumnya, homofobia merupakan satu sikap permusuhan dan penolakan terhadap lelaki dan wanita homoseksual (Fraisse \& Barrientos, 2016). Pengetahuan dan sikap terhadap homoseksual dilihat penting dalam membentuk sesebuah masyarakat. Oleh yang demikian, pendidikan dan pengetahuan mengenai sesuatu konsep dilihat mampu mempengaruhi sikap seseorang termasuk isu homoseksual ini (Kalra et al., 2010; Siva et al., 2020).

Justeru, kajian kuantitatif ini dijalankan bertujuan untuk mengkaji tentang pengetahuan pelajar sekolah agama tentang homoseksual iaitu sejauh mana kefahaman mereka terhadap isu ini serta bagaimana sikap dan penerimaan pelajar sekolah agama terhadap isu homoseksual ini. Seterusnya, kajian ini akan melihat sama ada terdapat hubungan antara pengetahuan homoseksual dengan sikap terhadap homoseksual dalam kalangan pelajar sekolah agama.

\section{Sorotan Literatur}

Kajian-kajian lepas didapati lebih tertumpu kepada perbincangan faktor penyebab berlakunya homoseksual dan gaya hidup homoseksual serta kemungkinan kembali pulih. Pelbagai faktor telah dikenal pasti yang menyumbang kepada kewujudan masalah ini. Faktor yang mempengaruhi penglibatan individu dalam homoseksual ini ada dinyatakan dalam kajian Ahmad et al. (2015) yang mengkaji tentang faktor dan cara gaya hidup serta kemungkinan kembali pulih dalam kalangan lesbian di sekitar Kota Bharu, Kelantan. Seramai enam orang responden dalam kalangan lesbian yang berbangsa Melayu dan beragama Islam yang terlibat dalam kajian ini. Dari hasil kajian ini didapati bahawa antara faktor yang mempengaruhi penglibatan dalam homoseksual ini adalah amalan keagamaan yang lemah, faktor keluarga dan rakan-rakan serta faktor pasangan sejenis yang lebih memahami. Kajian ini juga mendapati bahawa rata-rata responden melaporkan bahawa mereka selesa dengan gaya hidup yang telah sedia ada sebagai homoseksual dan hal ini menyebabkan keinginan mereka untuk kembali pulih berada pada tahap yang rendah.

Berdasarkan dapatan kajian yang dilaporkan oleh Fadzilah dan Noremy (2019) yang melibatkan lima orang responden lelaki mengenai hubungan sejenis dalam kalangan mahasiswa di Institusi Pengajian Tinggi Awam (IPTA), terdapat 10 faktor yang mempengaruhi individu yang terlibat dalam hubungan sejenis ini iaitu personaliti semula jadi individu, orientasi seksual, pengaruh persekitaran sosial, kurang kasih sayang daripada keluarga, kesunyian, pengalaman mengalami gangguan seksual, sokongan sosial yang berbentuk material, keinginan dan kepuasan seksual, rangsangan seksual dan pengaruh rakan sejenis. Walau bagaimanapun, salah satu faktor yang menyumbang kepada pembentukan individu ini adalah faktor keturunan (Khilman, 2016). Menurut Friedman (1998), kewujudan golongan homoseksual ini boleh dikaitkan dengan pelbagai faktor termasuk faktor genetik, biologi, kekeluargaan, naluri individu serta budaya internet dalam masyarakat.

Homoseksual merupakan satu fenomena yang tidak selari dengan perlembagaan Malaysia dan semua agama di Malaysia ini (Suhaya, 2017). Hukum hakam agama ini didasarkan kepada kitab suci dalam agama masing-masing iaitu Al-Quran, Vedas, Injil, Tripitaka, Adi Granth dan lain-lain lagi yang mana konsep dan nilai setiap agama itu dapat difahami bahawa homoseksual adalah suatu perbuatan yang 
dilarang (Zuraidah et al., 2018). Menurut perspektif Islam, homoseksual merupakan satu cara hidup yang salah dan melanggar prinsip agama. Hal ini adalah berdasarkan pandual Al Quran dan hadis sepertimana yang telah ditetapkan. Kajian Noor Hafizah et al. (2016) mengenai metodologi dakwah terhadap golongan LGBT ada menjelaskan bahawa tingkah laku homoseksual telah di jelaskan di dalam Al Quran iaitu Allah telah melaknat kaum nabi Luth kerana mereka telah ingkar dengan melakukan perbuatan homoseksual. Homoseksual jelas bertentangan dengan fitrah manusia yang asasnya manusia diciptakan lelaki untuk berpasangan dengan perempuan. Oleh yang demikian, kajian beliau telah menemui beberapa kaedah dakwah yang boleh diguna pakai bagi tujuan menyantuni individu homoseksual iaitu dengan menggunakan pendekatan psikologi, pembangunan sosial dan sahsiah, hiburan serta melalui dakwah bi al-ḥal. Menurut Imam Ibn Qayyim, beliau menyatakan bahawa homoseksual merupakan satu perbuatan maksiat dan tidak ada kerosakan yang lebih besar darinya (Ani \& Didin, 2018).

Kajian lepas turut mengkaji tentang perkaitan isu homoseksual dengan kesihatan mental yang membuktikan bahawa individu yang terlibat dengan homoseksual cenderung untuk terlibat dengan masalah kesihatan mental termasuk cubaan bunuh diri dan kecelaruan psikologi (Bell \& Weinberg, 1978; Hetrick \& Martin, 1987; Hammelman, 1993; Rotheram-Borum et al., 1994; Ahmad et al., 2015). Menurut American Psychiatric Association (2017), golongan gay dan lesbian mempunyai masalah kesihatan mental yang tinggi berbanding individu heteroseksual. Kenyataan ini dibuktikan melalui kajian oleh Siti Hajar et al. (2019) mengenai kecenderungan cubaan membunuh diri dalam kalangan gay dan lesbian di Malaysia. 11 orang daripada 25 orang klien gay dan lesbian dalam kajian ini didapati mempunyai kecenderungan untuk bunuh diri. Kajian ini melibatkan seramai enam orang responden daripada kaunselor berdaftar yang terlibat dengan klien homoseksual dalam sesi kaunseling. Hasil daripada kajian, tiga faktor yang menyumbang kepada kecenderungan bunuh diri dalam kalangan individu gay dan lesbian adalah faktor persekitaran, kemurungan dan konflik dalaman diri. Diskriminasi dan stigma masyarakat sekeliling telah menyebabkan wujudnya perasaan atau cubaan bunuh diri dalam golongan homoseksual sehingga boleh memberi kesan terhadap kesihatan fizikal dan mental golongan ini (Carrie et al., 2017).

Beberapa kajian terdahulu yang telah menjalankan kajian mengenai pengetahuan dan sikap terhadap homoseksual, menunjukkan bahawa kebanyakan responden menunjukkan mempunyai sikap yang negatif terhadap golongan homoseksual. Namun kebanyakan kajian mengenai sikap terhadap homoseksual adalah dijalankan ke atas individu atau responden yang mempunyai latar belakang pengajian perubatan. Sepertimana kajian oleh Ade Nea et al. (2018), kajian telah dijalankan ke atas 122 orang pelajar baharu di Universitas Padjadjaran, Indonesia. Hasil kajian beliau mendapati, sikap negatif terhadap homoseksual adalah tinggi dalam kalangan responden heteroseksual dan rata-rata pelajar masih kurang pengetahuan mengenai homoseksual. Kajian ini selaras dengan kajian Banwari et al. (2015) dan kajian Igor Grabovac et al. (2014) yang turut menjalankan kajian pengetahuan dan sikap homoseksual dalam kalangan pelajar perubatan. Berdasarkan kajian, rata-rata pengetahuan pelajar mengenai homoseksual berada pada tahap yang rendah dan sederhana. Malah hasil juga mendapati bahawa pelajar perempuan mempunyai sikap yang lebih positif terhadap homoseksual berbanding pelajar lelaki. Kajian-kajian mengenai pengetahuan dan sikap terhadap homoseksual ini kebanyakannya melibatkan pelajar perubatan dari luar negara dan perbincangan kajian lebih banyak tertumpu terhadap tahap pengetahuan dan sikap homoseksual. Namun, kajian pengetahuan dan sikap terhadap homoseksual ini masih kekurangan maklumat dan memerlukan lebih banyak kajian susulan di Malaysia.

\section{Metod Kajian}

Kajian ini adalah kajian kuantitatif yang menggunakan reka bentuk tinjauan. Data dikumpul menggunakan borang soal selidik secara atas talian bagi mendapatkan maklumat daripada responden. Jumlah responden yang terlibat dalam kajian ini adalah seramai 136 orang pelajar tingkatan empat, lima dan enam daripada dua buah sekolah iaitu Sekolah Menengah Agama Tarbiah Diniah (SMATD) dan Maahad Tahfiz Sains Darul Aman (MTSD). Seramai 96 orang pelajar daripada SMATD dan 40 orang daripada MTSD. Pemilihan sampel kajian adalah melalui kaedah persampelan rawak sistematik. 
Kajian ini menggunakan dua jenis instrumen iaitu The Sex Education and Knowledge about Homosexuality Questionnaire (SEKHQ) dan The Attitudes Towards Homosexuals Questionnaire (AHQ). Instrumen The Sex Education and Knowledge about Homosexuality Questionnaire (SEKHQ) mempunyai 32 item tentang pengetahuan homoseksual yang memerlukan responden untuk memberikan salah satu jawapan sama ada 'betul', 'salah' atau 'tidak tahu'. Skor bagi instrumen ini adalah berdasarkan jumlah item dari 0-32 yang mana sekiranya responden menjawab soal selidik dengan jawapan 'salah' atau 'tidak tahu', skor item adalah 0. Semakin tinggi skor bermaksud semakin tinggi pengetahuan responden mengenai homoseksual. Soal selidik ini digunakan hasil kompilasi daripada tiga kajian terdahulu iaitu kajian oleh Harris et al. (1995), Alderson et al. (2009) dan Wells et al. (1987). Nilai kebolehpercayaan instrumen ini adalah Alpha Cronbach 0.724.

Instrumen The Attitudes Towards Homosexuals Questionnaire (AHQ) juga merupakan hasil daripada kompilasi item-item yang telah digunakan dalam tiga kajian terdahulu iaitu kajian oleh Smith et al (2007), Morrison et al. (2002) dan Herek et al. (1988) yang mengandungi 20 item berkenaan sikap terhadap homoseksual yang merangkumi gaya hidup homoseksual dan kedudukan sosial. Instrumen ini adalah bagi mengenal pasti sikap, pandangan atau perspektif responden mengenai homoseksual. Sikap didefinisikan sebagai perasaan, idea, prasangka atau kepercayaan yang dimiliki oleh seseorang yang boleh mempengaruhi penerimaan seseorang individu terhadap sesuatu perkara. Sikap positif dalam kajian ini menggambarkan responden menerima golongan dan amalan homoseksual. Manakala sikap negatif pula menggambarkan responden menolak golongan dan amalan homoseksual sebagai gaya hidup. Instrumen ini berbentuk skala Likert yang mana sampel harus memberikan respons terhadap pernyataan berdasarkan lima pilihan jawapan iaitu $1=$ Sangat Setuju, $2=$ Setuju, $3=$ Agak Setuju, $4=$ Tidak Setuju, 5 = Sangat Tidak Setuju. Skala Likert ini digunakan untuk responden menyatakan darjah persetujuan terhadap item-item yang dikemukakan. Kaedah penskoran instrumen ini adalah dengan menjumlahkan keputusan setiap item yang diperoleh. Skor bagi skala ini adalah daripada 20-100 yang mana semakin tinggi skor, maka semakin negatif tingkah laku terhadap homoseksual. Nilai kebolehpercayaan instrumen ini adalah Alpha Cronbach 0.810 .

Kedua-dua soal selidik ini telah melalui proses terjemahan menggunakan kaedah back to back translation dengan bantuan dua orang pakar dalam bidang bahasa dan seterusnya mendapat pengesahan pakar oleh pensyarah Universiti Kebangsaan Malaysia. Data dianalisis menggunakan perisian Statistical Package For Sosial Science (SPSS) versi 20. Analisis deskriptif (min \& sisihan piawai) telah dijalankan untuk mengenal pasti objektif pertama iaitu perbezaan pengetahuan dan sikap terhadap homoseksual berdasarkan jantina dan umur. Bagi analisis inferensi pula, ujian-t digunakan untuk membandingkan antara dua kumpulan iaitu jantina responden. Manakala analisis varian sehala (ANOVA) digunakan untuk membandingkan umur responden. Korelasi Pearson juga telah digunakan untuk melihat hubungan antara pemboleh ubah dalam kajian ini.

\section{Hasil Kajian}

Jadual 1 menunjukkan taburan demografi responden yang terdiri daripada sekolah, jantina, umur dan orientasi seksual. Daripada keseluruhan 136 responden yang terlibat dalam kajian ini, seramai 40 (29.4\%) orang adalah daripada MTSD, manakala seramai 96 (70.6\%) orang lagi adalah daripada SMATD. Seramai $55(40.4 \%)$ orang adalah terdiri daripada lelaki, manakala seramai 81 (59.6\%) orang lagi adalah terdiri daripada perempuan. Responden yang dikaji adalah berumur diantara 16 hingga 18 tahun iaitu seramai 66 (48.5\%) orang berumur 16 tahun, 39 (28.7\%) orang berumur 17 tahun dan 31 $(22.8 \%)$ orang berumur 18 tahun. Bagi orientasi seksual, majoriti responden adalah dalam kalangan heteroseksual iaitu seramai $130(95.6 \%)$ orang. Diikuti dengan seramai $4(2.9 \%)$ orang homoseksual dan $2(1.5 \%)$ orang biseksual.

Berdasarkan dapatan daripada soal selidik yang telah diedarkan kepada 136 responden, 28 daripada 32 item SEKHQ mengenai pengetahuan tentang homoseksual menunjukkan bahawa kurang dari separuh peserta kajian yang menjawab item-item tersebut dengan betul. Selain itu, kurang daripada 10 peratus peserta kajian yang menjawab dengan betul pada 12 daripada 32 item yang mana item yang mencatat peratus terendah ialah item B31 iaitu "Dari segi sejarah, hampir setiap budaya telah membuktikan 
bahawa wujudnya sikap tidak bertoleransi terhadap homoseksual serta melihat golongan ini sebagai 'sakit' atau 'pendosa'” iaitu sebanyak 1.5 peratus sahaja. Item tertinggi yang telah dijawab dengan betul oleh peserta kajian ialah item B5 iaitu "Individu homoseksual biasanya mendedahkan identiti seksual mereka kepada rakan-rakan sebelum mereka memberitahu ibu bapa mereka" iaitu sebanyak 64.0 peratus. Secara keseluruhannya menunjukkan skor pengetahuan homoseksual dalam kalangan pelajar sekolah agama mencatatkan min 7.49 dan sisihan piawai 3.750. Manakala bagi menguji sikap terhadap homoseksual pula, hasil dapatan analisis bagi AHQ menunjukkan skor min item adalah berada antara 1.35 hingga 4.54. Secara keseluruhannya menunjukkan skor sikap terhadap homoseksual mencatatkan min 60.27 dan sisihan piawai 7.297.

Jadual 1: Taburan Demografi Responden

\begin{tabular}{lcc}
\hline & Bilangan & Peratus \\
\hline Sekolah & & \\
MTSD & 40 & 29.4 \\
SMATD & 96 & 70.6 \\
Jantina & & \\
$\quad$ Lelaki & 55 & 40.4 \\
Perempuan & 81 & 59.6 \\
Umur & & \\
16 tahun & 66 & 48.5 \\
17 tahun & 39 & 28.7 \\
18 tahun & 31 & 22.8 \\
Orientasi seksual & & \\
Heteroseksual & 130 & 95.6 \\
Homoseksual & 4 & 2.9 \\
Biseksual & 2 & 1.5 \\
\hline
\end{tabular}

Dua kaedah analisis digunakan untuk menganalisis perbezaan pengetahuan homoseksual dan sikap pelajar berdasarkan faktor demografi iaitu ujian-t dan juga analisis varian sehala (ANOVA). Hasil ujian-t yang menguji perbezaan pengetahuan homoseksual dan sikap pelajar terhadap homoseksual berdasarkan jantina responden dipaparkan dalam Jadual 4. Hasil ujian-t mendapati tidak terdapat perbezaan yang signifikan bagi pengetahuan homoseksual [ $\mathrm{t}=-0.637, \mathrm{p}=0.525$ ]; dan sikap terhadap homoseksual $[\mathrm{t}=0.982, \mathrm{p}=0.328]$ berdasarkan jantina responden. Berdasarkan keputusan kajian, min skor pengetahuan homoseksual lelaki ialah 7.24 lebih rendah daripada min skor pengetahuan perempuan iaitu 7.65. Perbandingan pengetahuan bagi lelaki dan perempuan ialah $\mathrm{t}=-0.637$ dan tahap signifikan lebih besar daripada 0.05 ( $\mathrm{p}>0.05)$. Hasil analisis perbezaan pengetahuan homoseksual berdasarkan jantina pelajar tidak menunjukkan mempunyai perbezaan. Maka hipotesis yang menyatakan tidak terdapat perbezaan yang signifikan pengetahuan homoseksual remaja berdasarkan jantina adalah diterima. Ini bermakna tidak terdapat perbezaan dalam pengetahuan homoseksual dan sikap pelajar terhadap homoseksual berdasarkan jantina responden seperti yang ditunjukkan pada jadual 2. Seterusnya, min skor sikap terhadap homoseksual bagi lelaki ialah 61.02, manakala min skor sikap terhadap homoseksual bagi perempuan ialah 59.77. Hasil analisis menunjukkan bahawa tidak ada perbezaan yang signifikan sikap terhadap homoseksual antara jantina lelaki dan perempuan. Oleh itu, hipotesis yang menyatakan tidak terdapat perbezaan yang signifikan sikap remaja terhadap homoseksual berdasarkan jantina adalah diterima. Ini menunjukkan tidak terdapat perbezaan sikap terhadap homoseksual berdasarkan jantina seperti yang ditunjukkan pada jadual 2.

Jadual 2: Perbezaan Pengetahuan Homoseksual Dan Sikap Pelajar Sekolah Agama Terhadap Homoseksual Berdasarkan Jantina

\begin{tabular}{ccccccc}
\hline & Jantina & N & Min & SP & Nilai t & Sig.P \\
\hline Pengetahuan & Lelaki & 55 & 7.24 & 3.410 & -.637 & .525 \\
homoseksual & Perempuan & 81 & 7.65 & 3.975 & & \\
Sikap terhadap & Lelaki & 55 & 61.02 & 6.536 & .982 & .328 \\
homoseksual & Perempuan & 81 & 59.77 & 7.771 & & \\
\hline
\end{tabular}


Hasil analisis varian sehala bagi menguji perbezaan pengetahuan homoseksual berdasarkan umur responden dipaparkan dalam Jadual 3. Hasil analisis menunjukkan tidak terdapat perbezaan yang signifikan bagi pengetahuan homoseksual $[\mathrm{F}(2,133)=1.384, \mathrm{p}=0.254]$ berdasarkan umur responden. Ini bermakna tidak ada perbezaan dalam pengetahuan homoseksual dan sikap pelajar terhadap homoseksual berdasarkan umur responden. Maka, hipotesis yang menyatakan tidak terdapat perbezaan dalam pengetahuan homoseksual berdasarkan umur adalah diterima.

Jadual 3: Perbezaan Pengetahuan Homoseksual Berdasarkan Umur

\begin{tabular}{llccccc}
\hline & & JKD & DK & MKD & F & Sig. P \\
\hline \multirow{2}{*}{ Pengetahuan } & Antara kumpulan & 38.700 & 2 & 19.350 & 1.384 & .254 \\
homoseksual & Dalam kumpulan & 1859.271 & 133 & 13.979 & & \\
& Jumlah & 1897.971 & 135 & & & \\
\hline
\end{tabular}

Dalam pada itu, jadual 4 menunjukkan hasil analisis varian sehala bagi perbezaan sikap pelajar terhadap homoseksual berdasarkan umur responden. Hasil analisis menunjukkan tidak terdapat perbezaan yang signifikan bagi sikap terhadap homoseksual $[\mathrm{F}(2,133)=0.697, \mathrm{p}=0.500]$ berdasarkan umur responden. Ini bermakna, hasil analisis menunjukkan hipotesis yang menyatakan tidak ada perbezaan dalam sikap pelajar terhadap homoseksual berdasarkan umur responden adalah diterima.

Jadual 4: Perbezaan Sikap Pelajar Sekolah Agama Terhadap Homoseksual Berdasarkan Umur

\begin{tabular}{ccccccc}
\hline & & JKD & DK & MKD & F & Sig. P \\
\hline \multirow{2}{*}{ Sikap terhadap } & Antara kumpulan & 74.552 & 2 & 37.276 & .697 & .500 \\
homoseksual & Dalam kumpulan & 7114.381 & 133 & 53.492 & & \\
& Jumlah & 7188.934 & 135 & & & \\
\hline
\end{tabular}

Hasil analisis korelasi yang dipaparkan dalam Jadual 6 menunjukkan keputusan pengujian hipotesis kesan langsung menghasilkan satu dapatan penting, iaitu pengetahuan homoseksual $(r=0.034, p>$ 0.05) tidak mempunyai hubungan yang signifikan dengan sikap pelajar terhadap homoseksual.

Jadual 5: Hubungan Antara Pengetahuan Homoseksual dengan Sikap Terhadap Homoseksual

\begin{tabular}{ccc}
\hline & \multicolumn{2}{c}{ Pengetahuan } \\
\cline { 2 - 3 } & $\mathbf{r}$ & Sig. P \\
\hline Sikap terhadap homoseksual & -.034 & .691 \\
\hline
\end{tabular}

Berdasarkan interpretasi koefisien korelasi Guilford (1956), hubungan antara pengetahuan homoseksual dengan sikap pelajar terhadap homoseksual adalah negatif dan sangat lemah memandangkan nilai yang diperoleh adalah kurang daripada 0.20. Hal ini bermaksud, pengetahuan pelajar tentang homoseksual tidak mempengaruhi sikap pelajar sekolah agama terhadap homoseksual. Semakin tinggi pengetahuan tentang homoseksual, maka ia akan menghasilkan sikap yang negatif terhadap homoseksual. Begitu juga sebaliknya jika pengetahuan homoseksual adalah rendah, maka sikap terhadap homoseksual dalam kalangan pelajar sekolah agama akan menghasilkan sikap yang positif. Oleh itu, hipotesis yang menyatakan tidak terdapat hubungan antara pengetahuan homoseksual dengan sikap homoseksual dalam kalangan pelajar sekolah agama adalah diterima.

\section{Perbincangan Kajian}

Hasil kajian yang dijalankan mendapati bahawa tidak terdapat perbezaan dalam pengetahuan homoseksual dan sikap pelajar terhadap homoseksual berdasarkan jantina dan umur responden. Seterusnya, analisis kajian juga mendapati bahawa tiada hubungan antara pengetahuan homoseksual dengan sikap pelajar terhadap homoseksual. Oleh yang demikian, kajian merumuskan bahawa 
pengetahuan homoseksual dan sikap terhadap homoseksual adalah dua perkara yang berbeza dan saling tidak berhubungan. Jantina responden secara jelasnya tidak membezakan pengetahuan responden mengenai homoseksual. Kajian ini menunjukkan beberapa persamaan dengan kajian Banwari et al. (2015) mengenai pengetahuan dan sikap terhadap homoseksual terhadap pelajar dan pelatih perubatan. Kajian beliau mendapati tidak terdapat perbezaan yang ketara mengenai pengetahuan responden berdasarkan jantina lelaki dengan perempuan. Manakala kajian Della Pelle et al. (2018) pula menunjukkan bahawa jantina perempuan mempunyai pengetahuan tentang homoseksual yang lebih tinggi berbanding jantina lelaki dalam kalangan jururawat Itali.

Seterusnya, bagi dapatan kajian mengenai pengetahuan homoseksual berdasarkan faktor umur turut menunjukkan tiada perbezaan yang signifikan antara pelajar tingkatan empat, lima dan enam di keduadua buah sekolah dalam kajian ini. Hal ini bertentangan dengan dapatan Banwari et al. (2015) yang mendapati dalam kalangan respondennya, pelajar pelatih dan pelajar perubatan tahun tiga mempunyai pengetahuan yang lebih baik berbanding pelajar perubatan tahun satu dan dua. Kajian ini berbeza dengan kajian-kajian yang telah sedia ada kerana kajian ini menggunakan sampel kajian dalam kalangan pelajar sekolah menengah yang mempunyai latar pendidikan agama. Kebanyakan kajiankajian terdahulu lebih memfokuskan kepada sampel dalam kalangan pelajar pengajian tinggi. Hal ini dibuktikan dengan kajian Banwari et al. (2015), Della et al. (2018), Ade et al. (2018) dan kajian Raphael et al. (2020) yang rata-rata sampel kajian adalah pelajar pengajian tinggi dalam bidang perubatan. Kajian mengenai pengetahuan dan sikap terhadap homoseksual masih tidak banyak dijalankan di dalam negara Malaysia. Kajian dalam Malaysia berhubung isu homoseksual ini banyak membincangkan tentang faktor-faktor yang membawa kepada isu ini sepertimana kajian yang telah dijalankan oleh Fadzilah (2019) yang menjalankan kajian ke atas lima orang pelajar IPTA yang berumur lingkungan 21 hingga 26 tahun.

Hasil dapatan kajian ini juga menunjukkan bahawa tidak ada perbezaan yang signifikan bagi sikap terhadap homoseksual berdasarkan jantina dan umur pelajar. Jantina dan umur tidak menjadi ukuran kepada sikap terhadap homoseksual. Kajian ini menunjukkan rata-rata pelajar menunjukkan sikap yang negatif terhadap homoseksual dan hasil dapatan ini menunjukkan tiada perbezaan antara sikap pelajar lelaki dan perempuan terhadap homoseksual. Dapatan ini bertentangan dengan kajian Banwari et al. (2015), Grabovac et al. (2014), Teh et al. (2016), Della et al. (2018) dan Mary (2020) yang melaporkan dalam kajian mereka bahawa terdapat perbezaan sikap antara pelajar lelaki dengan pelajar perempuan iaitu pelajar perempuan didapati mempunyai sikap yang lebih positif terhadap homoseksual berbanding pelajar lelaki. Kajian-kajian mereka mendapati bahawa jantina perempuan lebih bersifat empati dan tidak menghukum terhadap isu homoseksual ini berbanding dengan lelaki. Dari aspek umur pula, kajian ini telah menunjukkan tiada perbezaan antara umur pelajar dengan sikap terhadap homoseksual ini. Namun bagi kajian Grabovac et al. (2014), faktor umur ini mempunyai kesan perbezaan pada sikap pelajar terhadap homoseksual iaitu pelajar tahun enam menunjukkan sikap yang lebih positif berbanding pelajar tahun lima sehingga mendapat ugutan berbentuk lukisan senapang dan swastika pada kertas soal selidik yang telah dijawab oleh pelajar tahun lima.

\section{Hubungan antara Pengetahuan Homoseksual dengan Sikap Pelajar Sekolah Agama Terhadap Homoseksual}

Pelbagai faktor yang boleh mempengaruhi sikap terhadap homoseksual, dan salah satu faktor adalah pengetahuan terhadap homoseksual. Kajian Banwari et al. (2015) yang juga menggunakan instrumen yang sama mendapati bahawa pengetahuan terhadap homoseksual mempunyai pengaruh yang kuat terhadap sikap homoseksual yang mana pengetahuan yang baik mengenai homoseksual akan membawa kepada sikap yang positif terhadap homoseksual dan begitu juga sebaliknya. Namun kajian ini pula menunjukkan bahawa pengetahuan tentang homoseksual tidak mempengaruhi sikap pelajar terhadap homoseksual. Hal ini dibuktikan dengan hasil dapatan yang menjawab persoalan kajian kedua iaitu tidak ada hubungan yang signifikan antara pengetahuan homoseksual $(r=0.034, p>0.05)$ dengan sikap pelajar terhadap homoseksual. Latar belakang pelajar yang mempunyai pendidikan agama ini mungkin menjadi faktor kepada sikap mereka terhadap homoseksual sama ada mereka mempunyai pengetahuan mengenai homoseksual ataupun tidak. Faktor kurangnya penghayatan agama menjadi 
salah satu faktor utama dalam isu homoseksual. Sebagaimana kajian Ahmad et al. (2015), kajian beliau mendapati bahawa faktor utama keterlibatan remaja dalam homoseksual adalah kurangnya penghayatan agama, faktor keluarga dan pengaruh rakan dan keserasian antara pasangan yang sama jantina (Ahmad et al., 2015).

Pengkaji menganggarkan bahawa responden kajian daripada dua buah sekolah agama ini mempunyai pengetahuan agama dan lebih arif mengenai hukum hakam atau perkara yang dilarang dalam agama. Agama tidak dapat dipisahkan dengan nilai-nilai kebaikan yang mana nilai ini merangkumi hak asasi manusia. Malah dalam mana-mana agama sekalipun amat menitik beratkan nilai dan budaya yang baik seperti amanah, jujur keburukan arak, berjudi dan berzina sama ada individu heteroseksual mahupun homoseksual. Hukum hakam agama ini didasarkan kepada kitab suci dalam agama masing-masing iaitu Al-Quran, Vedas, Injil, Tripitaka, Adi Granth dan lain-lain lagi yang mana konsep dan nilai setiap agama itu dapat difahami bahawa homoseksual adalah suatu perbuatan yang dilarang (Zuraidah et al. 2018). Maka dapat difahami bahawa homoseksual merupakan satu perbuatan yang dilarang dan bercanggah dengan agama. Oleh yang demikian, hasil yang diperoleh dalam kajian ini yang menunjukkan sikap terhadap homoseksual tidak dipengaruhi oleh pengetahuan pelajar tentang homoseksual adalah mungkin atas faktor penghayatan atau pengetahuan agama mereka.

Kesedaran budaya merujuk kepada kesedaran terhadap nilai dan warisan budaya yang mana ia boleh mempengaruhi interaksi dan persepsi dengan kumpulan yang pelbagai. Maka kesedaran budaya ini mempengaruhi sikap dan kepercayaan seseorang. Pengetahuan tentang kumpulan yang pelbagai termasuk dalam penghormatan dan penghargaan terhadap perbezaan budaya-budaya lain (Sue et al., 1982). Oleh yang demikian, berdasarkan keputusan kajian yang diperoleh, responden menunjukkan secara jelas tentang budaya dan kepercayaan yang dipegang. Pengkaji menganggarkan responden kajian ini berpegang teguh dengan agama yang berlandaskan Al-Quran dan hadis. Hal ini kerana, kajian ini menunjukkan responden tetap mempunyai sikap yang negatif terhadap homoseksual meskipun mereka mempunyai pengetahuan tentang homoseksual.

Pelajar mungkin mempunyai sikap menghormati terhadap agama dan budaya yang lain sepertimana kajian oleh Azizi et al. (2015) yang telah melihat enam sikap pelajar sekolah agama. Kajian beliau mendapati pelajar mempunyai kecenderungan yang tinggi terhadap sikap menghormati, kesedaran berinteraksi dan toleransi. Namun pelajar mempunyai kesukaran dalam aspek keselesaan berinteraksi, semangat kejiranan dan kesediaan untuk berkongsi kepelbagaian. Kajian Azizi et al. (2015) boleh dikaitkan dengan hasil kajian ini yang mana pelajar mungkin boleh menghormati dan bertoleransi dalam beberapa aspek berkaitan kepelbagaian budaya. Bagi isu homoseksual yang dilihat sebagai satu budaya yang menyimpang dari ajaran agama, agak sukar bagi golongan pelajar sekolah agama ini untuk menerima homoseksual sebagai salah satu kepelbagaian budaya. Maka kajian ini melihat bahawa responden kajian mempunyai pegangan budaya dan kepercayaan mereka sendiri yang mana ia telah membentuk identiti mereka sebagai pelajar sekolah agama. Masyarakat yang menentukan bentuk kehidupan mereka sendiri dan ketika di dalam kelompok, mereka mematuhi kepada sistem dan nilai yang dipegang (Jaffary et al., 2008). Selain itu, sebahagian besar responden dalam kajian merupakan golongan heteroseksual. Oleh itu, orientasi seksual menjadi salah satu faktor kepada sikap terhadap homoseksual iaitu individu heteroseksual mempunyai sikap yang negatif terhadap homoseksual. Sepertimana di kajian-kajian lepas, individu yang berpegang dengan nilai dan budaya yang utuh akan menunjukkan sikap negatif terhadap homoseksual. Oleh itu, hal ini akan menyebabkan stigma mengenai homoseksual mempengaruhi responden.

\section{Kesimpulan}

Kajian ini jelas menunjukkan bahawa tidak terdapat hubungan antara pengetahuan homoseksual dengan sikap pelajar sekolah agama terhadap homoseksual. Selain itu, kajian ini juga menunjukkan tidak terdapat perbezaan antara pengetahuan homoseksual dengan sikap terhadap homoseksual walaupun dari aspek demografi responden. Berdasarkan dapatan kajian ini, walaupun responden mempunyai pengetahuan mengenai homoseksual, tetap tidak mengubah persepsi negatif mereka terhadap homoseksual yang seterusnya boleh mempengaruhi sikap mereka terhadap golongan 
homoseksual. Namun jika sebaliknya, sekiranya responden mempunyai pengetahuan yang kurang mengenai homoseksual, berkemungkinan responden akan menunjukkan sikap yang positif terhadap homoseksual. Hal ini menunjukkan hasil kajian ini berbeza dengan kajian-kajian terdahulu.

Secara keseluruhannya, beberapa perkara penting dalam kajian ini yang menjadi justifikasi penting bagi kajian ini adalah pengetahuan dan sikap pelajar sekolah agama terhadap homoseksual. Terdapat lima aspek yang mempengaruhi persoalan yang membezakan kajian ini dengan kajian-kajian terdahulu iaitu latar belakang pendidikan responden dalam kalangan pelajar sekolah agama, penghayatan dan pengetahuan agama, budaya dan kepercayaan serta orientasi seksual. Dalam aspek budaya, kajian ini menunjukkan bahawa responden memegang identiti mereka sebagai pelajar sekolah agama yang mana mereka berpegang bahawa mereka perlu mematuhi kepada nilai, sistem atau kepercayaan yang telah dibentuk. Hal ini membentuk sikap atau penerimaan mereka terhadap homoseksual. Masyarakat tidak dapat lari daripada sikap negatif terhadap homoseksual ini biarpun di dalam negara Malaysia mahupun di negara-negara luar. Lebih-lebih lagi bagi negara Malaysia yang mengamalkan sistem perundangan yang berpandukan agama Islam. Jelas dalam undang-undang bahawa homoseksual atau LGBT tidak diiktiraf dalam perundangan Malaysia malah dianggap sebagai satu jenayah bagi individu yang beragama Islam sahaja (Izzat, 2018).

Kajian ini terhad kepada beberapa limitasi. Oleh itu, pengkaji mencadangkan beberapa cadangan kajian berkenaan pengetahuan dan sikap terhadap homoseksual yang boleh dilakukan dalam kajian lanjutan. Dalam aspek kaedah kajian, kajian ini terhad kepada kaedah kuantitatif sahaja. Kajian-kajian lepas pula banyak menggunakan kaedah kualitatif. Oleh itu, bagi kajian lanjutan dicadangkan agar melaksanakan lebih banyak kaedah kuantitatif ataupun kaedah gabungan antara kuantitatif dan kualitatif agar dapat menggambarkan dengan lebih jelas mengenai pengetahuan dan sikap terhadap homoseksual. Dari aspek peserta kajian pula, peserta kajian ini hanya terhad kepada pelajar sekolah menengah agama sahaja iaitu pelajar dari tingkatan empat, lima dan enam. Kajian lanjutan boleh dilakukan dengan melibatkan peserta kajian yang tidak terhad kepada pelajar sekolah agama sahaja. Malah boleh melibatkan peserta kajian daripada pelbagai peringkat umur dari institusi yang berbeza-beza. Seterusnya, kajian ini menggunakan instrumen soal selidik iaitu instrumen SEKHQ dan AHQ bagi memperoleh data berkaitan pengetahuan homoseksual dan sikap terhadap homoseksual. Oleh itu, kajian lanjutan dicadangkan agar menggunakan instrumen yang berbeza bagi melihat kefahaman peserta kajian terhadap homoseksual. Selain itu, temu bual juga boleh dilaksanakan bagi mengetahui gambaran sebenar mengenai pengetahuan dan persepsi terhadap homoseksual. Cadangan kajian lanjutan ini adalah bertujuan bagi penambahbaikan kepada kajian akan datang. Kajian ini diharapkan agar dapat memberi pengetahuan dan rujukan kepada kajian-kajian di masa hadapan untuk meneliti dengan lebih mendalam lagi mengenai kajian ini.

\section{Rujukan}

Abdullah \& Md Akhir. (2019). LGBT dalam Kalangan Mahasiswa di Institusi Pengajian Tinggi Awam. Jurnal Wacana Sarjana, 3(4), 1-11. Retrieved from http://spaj.ukm.my/jws/index.php/jws/article/view/286

Adams, Wright \& Lohr. (1996). Is Homophobia Associated With Homosexual Arousal? Journal of Abnormal Psychology, 105, 440-445.

Ade Nea, Rudi Wisaksana \& Enny Rohmawaty. (2018). Knowledge, Attitude, and Behavior Regarding Homosexualilty among New Students in Universitas Padjadjaran. Althea Medical Journal, 5(4).

Ahmad, Haikal Anuar Adnan, Abd Satar, Wan Shahrazad Wan Sulaiman, Wan Azreena, Zainal Abidin \& Wan Mohd Zain. (2015). Faktor Dan Cara Gaya Hidup Serta Kemungkinan Kembali Pulih Dalam Kalangan Lesbian: Satu Kajian Kes. Journal of Social Sciences and Humanities, 10(1), 1-15.

American Psychiatric Association. (2017). Mental Health Disparities: LGBTQ. Division of Diversity and Health Equity.

Ani Khairani \& Didin Saefudin. (2018). Homoseksual Berdasarkan Pandangan Psikologi Islam. Jurnal Pendidikan Islam, 7(2), 1-23. 
Banwari, Mistry, Soni, Parikh \& Gandhi. (2015). Medical Students and Interns' Knowledge About and Attitude Towards Homosexuality. J Postgrad Med, 61(2), 95-100.

Bell \& Weinberg. (1978). Homosexualities: A Study Of Diversity Among Man And Women. New York: Simon and Schuster.

Carrie Lee, John Oliffe, Mary Kelly \& Olivier Ferlatte. (2017). Depression and Suicidality in Gay Men: Implications for Health Care Providers. American Journal of Men Health, 11(4), 910-9.

Della Pelle, Cerratti, Di Giovanni, Cipollone \& Cicolini. (2018). Attitudes Towards and Knowledge About Lesbian, Gay, Bisexual, and Transgender Patients Among Italian Nurses: An Observational Study. J Nurs Scholarsh, 50(4), 367-374. doi: 10.1111/jnu. 12388. Epub 2018 Apr 24. PMID: 29689129.

Fraïsse \& Barrientos. (2016). The concept of homophobia: A Psychosocial Perspective. Sexologies, 25(3), 133-140 http://dx.doi.org/10.1016/j.sexol.2016.02.002

Friedman. (1998). Homosexuality. Journal of Psychological Association. 69-79.

Guilford. (1956). Fundamental Statistics in Psychology and Education. McGraw Hill.

Hammelman. (1993). Gay and Lesbian Youth: Contributing Factors to Serious Attempts or Considerations of Suicide. Journal of Gay and Lesbian Psychotherapy, 2, 77-89.

Hetrick \& Martin. (1987). Developmental Issues and their Resolution for Gay and Lesbian Adolescents. Journal of Homosexualities, 14, 25-43.

Hogan \& Hudson. (1998). Completely Queer: The Gay and Lesbian Encyclopedia. Henry Holt.

Hyde. (2017). Understanding Human Sexuality. McGraw Hill.

Jaffary Awang, Rozmi Ismail, Kamaruddin Salleh \& Hairunnizam Wahid. (2008). Sosialisasi Agama

Di Kalangan Pelajar-Pelajar Sekolah Agama Di Selangor. National Seminar Science, Technology and Social Science 2008. Kumpulan Kajian Dunia Melayu \& Islam, Institut Alam dan tamadun Melayu (ATMA), Universiti Kebangsaan Malaysia.

Kalra, Gupta \& Bhugra. (2010). Sexual variation in India: A view from the west. Indian J Psychiatry, 52:S264-8.

Khairul Anwar. (2015). Suami Gay, Isteri Mak Nyah. Cetakan pertama. PTS Publication \& Distributors Sdn. Bhd. Kuala Lumpur.

Kite. (1994). When Perceptions Meet Reality: Individual Differences in Reactions to Lesbians and Gay Men. In: Greene B, Herek G (Eds), Lesbian and Gay Psychology: Theory, Research and Clinical Applications. Sage Publications, Thousand Oaks.

Mary Egan. (2020). Attitudes Toward LGBTQ Individuals in the New Jersey Health Sector. Doctoral Dissertation. Walden University.

Mohamad Afandi Md Ismail \& Mohd Sabree Nasri. (2019). Gejala Lgbt Di Malaysia: Isu dan Cadangan Penyelesaian. Journal of Law \& Governance Volume, 2 (1), 51-65.

Mohd Izzat Amsyar Mohd Arif, Muhammad Syahlan Shafie, Hisham Hanapi \& Fareed Mohd Hassan. (2018). Salah Laku Lgbt Dalam Perundangan Malaysia: Undang-Undang Sebagai Mekanisme Pembanterasan dan Kawalan. Journal of Advanced Research in Social and Behavioural Sciences 13(1), 19-34.

Ng, Tan, Gill, Koh, Jambunathan, Pillai \& Sidi. (2013). Reliability And Validity Of The Malay Version Of Attitude Toward Lesbians And Gay Men (MVATL/MVATG): A Study On a Group Of Medical Students In Malaysia. Asia Pacific Psychiatry, 5,118-122.

Noor Hafizah Haridi, Kamal Azmi Abd. Rahman \& Rosni Wazir. (2016). Metodologi Dakwah Terhadap Golongan Lesbian, Gay, Biseksual Dan Transgender (LGBT). Jurnal Pengajian Islam, $9(2)$.

Osmanaga. (2015). Students Attitudes Toward Homosexuality. European Scientific Journal, 11(23),170-184.

Puteri Hayati Megat Ahmad \& Nurul Hudani Md Nawi. (2015). Latar Belakang, Faktor Pengekalan Dan Pandangan Terhadap Tingkah Laku Mahasiswa Lelaki Kecelaruan Identiti Gender. Journal Southeast Asia Psycholoy, 1.

Roslee Ahmad, Salleh Amat, Mohd Isa Amat, Rezeki Perdani Sawai, Muhammad Khairi Mahyuddin \& Ahmad Najaa Mokhtar. (2017). Pembangunan Alat Ukur Orientasi Seks Perlakuan Gay Dan Lesbian. Journal Psikologi dan Kaunseling, 175-193.

Rotheram-Borus \& Fernandez. (1995). Sexual Orientation and Developmental Challenges Experienced By Gay and Lesbian Youths. Suicide And Life Threatening Behaviour, 25, 26-34 
Sadock Benjamin, Sadock Virginia \& Ruiz. (2015). Kaplan \& Sadock's Synopsis of Psychiatry: Behavioral Sciences/Clinical Psychiatry. 11th ed. Philadephia: Lippincott Williams \& Wilkins. p. 564-72.

Schellenberg, Hirt \& Sears. (1999). Attitudes Toward Homosexuals Among Students At a Canadian University. Journal of Sex Roles, 20.

Siti Hajar Jamal, Salleh Amat \& Nasrudin Subhi. (2019). Kecenderungan Cubaan Membunuh Diri dalam Kalangan Gay dan Lesbian di Malaysia. Jurnal Pendidikan Malaysia 44(1), 151-162.

Siva Ilango, Karthikeyan, Sumithra Devi, Arumuganathan, Usaid \& Sethumadhavan. (2020). An Online Survey Of Education, Knowledge And Attitude Toward Homosexuality In Adults. Indian J Soc Psychiatry, 36, 344-50

Steve Hogan dan Lee Hudson. (1998). Completely Queer: The Gay and Lesbian Encyclopedia. Henry Holt.

Sue, Bernier, Durran, Feinberg, Pedersen, Smith \& Vasques-Nuttal. (1982). Position Paper: Crosscultural counseling competancies. The Counseling Psychologist, 10, 45-52.

Suhaya Deraman, Salasiah Hanin Hamjah, Ahmad Irdha Mokhtar, Anis Nor Amelia Nor Asikin \& Izzah Nur Aida Zur Raffar. (2017). Identifikasi Identiti Biseksual dan Hubungannya dengan Aspek Sokongan Sosial dan Kesihatan Mental. Journal Of Islamic Dakwah, 9(2).

Teh Sin Ting, Ee Siu Kwin \& Pua Xinyi. (2016). Factors Affecting Attitudes Toward Homosexuals Factors Affecting Attitudes Toward Homosexuals Among Undergraduate Students In Malaysia. Research Project The Bachelor Of Social Science (Hons) Psychology Faculty Of Arts And Social Science, Universiti Tunku Abdul Rahman.

Wahlen, Bize, Wang, Merglen \& Ambresin. (2020). Medical Students' Knowledge Of And Attitudes Towards Lgbt People And Their Health Care Needs: Impact Of a Lecture On Lgbt Health. PLoS ONE 15(7): e0234743. https://doi.org/10.1371/journal.pone.0234743 